\title{
Evaluation of Lactobacillus spp. based on phenotypical profile as direct-fed microbial candidate for poultry nutrition
}

\section{Mihaela Dumitru' ${ }^{1}$, Georgeta Ciurescu' ${ }^{1}$, Mihaela Hăbeanu ${ }^{1}$}

*corresponding author: mihaela.dumitru22@yahoo.com

${ }^{1}$ Department of Animal Nutrition and Biotechnology, National Research and Development Institute for Biology and Animal Nutrition (IBNA), 077015

\section{ABSTRACT}

The present study was conducted to isolate, identify and characterize a lactic acid bacteria strain from turkey ileum content (46-day-old). The new strain was phenotypical confirmed as Lactobacillus acidophilus (L. acidophilus) and conserved under the code IBNA 09. Bacterial profile of L. acidophilus was compared with other strains known as L. paracasei CCM 1837 and L. plantarum ATCC 8014, based on cultural, morphological, biochemical and enzymatic activity (amylase and cellulase). The strains appear as Gram positive bacilli, thin, non-spore-forming, isolated, diplo form, in short chains or in small irregular piles on Man Rogosa and Sharp (MRS) broth and agar medium. The identification and biochemical traits were performed by catalase assay, API 50 CHL V 5.1 soft (L. acidophilus biotype 2, 99.9\% ID; good identification to the genus $L$. paracasei spp. paracasei 1 or $3,48-51 \%$ ID; $L$. plantarum 1, 99.9\% ID) and ABIS online (L. acidophilus 88\%; L. paracasei spp. paracasei, $\sim 90 \%$; L. plantarum, $\sim 91 \%$ ). The highest total score of extracellular amylase activity was recorded by L. acidophilus IBNA 09 at 24-48 h $(5.10 \pm 0.176 \mathrm{U} / \mathrm{mL}, 4.99 \pm 0.409 \mathrm{U} / \mathrm{mL})$, follow by L. paracasei CCM $1837(0.12 \pm 0.002 \mathrm{U} / \mathrm{mL}, 0.15 \pm 0.001 \mathrm{U} / \mathrm{mL})$. During entire period, cellulase production was observed only for $L$. acidophilus $(0.28 \pm 0.019 \mathrm{U} / \mathrm{mL})$, comparative with $L$. paracasei where the activity was observed in the first 24 $\mathrm{h}$, respectively at $72 \mathrm{~h}$ for $L$. plantarum. These results suggest that $L$. acidophilus IBNA 09 possesses potential probiotic traits as a suitable candidate for amylase and cellulase production, and starter culture can improve cereal fermentation and the process of digestion in poultry nutrition. poultry

Keywords: Lactobacillus spp., identification, enzymatic activity, probiotic, 


\section{INTRODUCTION}

Addition as live microorganisms in animal feed, probiotics determine an increase of nutritional value of material raw, with inhibition of antinutritional factors from forages, maximizing the enzymatic profile of nutrients for improving the zootechnical efficiency (Bedford, 2001).

The GI microbiota of monogastric animal has an essential role in health, nutrition, and animal performance (Pieper et al., 2006). Probiotics represent a high number of multiple beneficial effects between intestinal bacteria and effects on the body host (Kizerwetter -Swida and Bineak, 2016). Some beneficial effects can be associated with another organic acid, hydrogen peroxide, competition for nutrients, capability to reduce adherence, and colonization of pathogenic bacteria in GI (Kizerwetter -Swida and Bineak, 2016; Walter, 2008). Microbiota is composed essentially from bacteria, generally Gram-positive (aerobic and facultative anaerobes as lactobacilli, streptococci); the numbers of bacteria range from 400 to 500 with an increase from proximal to distal GI (Richards et al., 2005). Colon and faeces content can present up to $10^{10}-10^{12}$ bacterial cells (Richard et al., 2005). For example, the density and diversity of the lactobacilli in the human body increases from the proximal level of the small intestine $\left(10^{3} \mathrm{CFU} / \mathrm{mL}\right.$ luminal content in the duodenum) to the colon (up to $10^{8} \mathrm{CFU} / \mathrm{mL}$ ) compared to some animal species which has an abundant spectrum of bacteria (especially lactobacilli), starting with the proximal intestine (Walter, 2008). The addition of probiotic bacteria occurs an important place in the animal body due to their implication to inhibit and control enteric pathogens along with improving the functioning and production capacity of animals (Anee et al., 2018).

The administration of probiotics in animal feed can prevent GI disorders (changes in composition of intestinal microbiota) by GIT colonization, preservation of microbiota stability and prevention of pathogens (Vamanu et al., 2015). Probiotics addition increases the resistance to Salmonella spp. infections (Menconi, 2013a; Dumitru et al., 2021a,b). The most common bacteria used as probiotic supplements are lactic acid bacteria (LAB) from the genus Lactobacillus and Pediococcus (Latorre et al., 2016), and the species from the present genus are known as non pathogenic bacteria with capacity to form lactic acid as the principal metabolic end product of sugar process (Walter, 2008).

LAB can be found in plants or material of vegetable origin, silage, fermented food (yogurt, cheese, olives, pickles, salami, etc.), as well as in the oral cavities, GIT, and vaginas of humans and animals (Walter, 2008). LABs are bacteria with implications in terms of animal nutrition, improving nutritional's value of the GI microbial ecosystem in monogastric animals (poultry, pigs etc.) and some biological functions can be improved for the host (Yelnetty et al., 2014; Bakari et al., 2011). Lactobacillus spp. develop a low 
proteolytic and lipolytic enzymatic activity, but can release significant amounts of exogenous enzymes (amylase and cellulase) in the culture medium, favouring the higher degradation of starch and cellulose found in animal forages (Padmavathi et al., 2018; Dumitru et al., 2016). The use of enzymes produced from Lactobacillus is known as safe because, as affirmed Singh et al., (2006), they are non-pathogenic bacteria.

The objective of this work was to isolate, identify and evaluate a Lactobacillus strain present in the broiler's turkey GIT (ileum content) and to determine the enzymatic activity compared with two reference strains, as preliminary investigation for use as probiotic candidate in poultry nutrition

\section{MATERIALS AND METHODS}

\section{Statement of Ethics}

A total of 288 one-d-old Hybrid Grade maker male turkey (0-70 feeding day trial), housed in the Experimental Biobase of National Research Development Institute for Biology and Animal Nutrition (IBNA) Balotesti were randomly selected for this topic. The bird's care and use protocol were approved by the Animal Ethics Committee at the IBNA, following the principles of EU Directive 2010/63/EU as transposed to Romanian legislation on Animal Protection used for Scientific Purposes (Law no. 199/2018).

\section{Lactobacillus Strain}

Lactobacillus strain isolated from turkey GIT (46-day old) was phenotypically and enzymatically (amylase and cellulase activity) investigated. The results were compared with other two reference strains: $L$. paracasei CCM 1837 (LC) and L. plantarum ATCC 8014 (LP). The identification of all strains was done by biochemical assay (catalase, API 50 CHL Biomerieux strips, and ABIS online soft).

All strains were evaluated for enzymatic activity by Hostettler's method for amylase enzyme and Petterson's and Porath's method for cellulase enzyme at 24,48 , and $72 \mathrm{~h}$, at $37^{\circ} \mathrm{C}$. The research was carried out at the Laboratory of Biotechnology of National Research Development Institute for Biology and Animal Nutrition Balotești (INCDBNA), Romania.

\section{Samples Collection for Bacterial Isolation}

The sample of broiler turkey intestinal content (ileum) was collected by cervical dislocation after which their crop and intestine was aseptically removed, placed in sterile plastic bags, and immediately carried to the laboratory in box with ice for microbiological analysis. 
Isolation of LAB. Morphological and cultural characters

After collected of the intestinal content, 1 gram from ileum was aseptically removed and enriched in MRS broth (Man, Rogosa, Sharpe from Oxoid CM0361), homogenized and incubated at $37^{\circ} \mathrm{C}$, for 24,48 and $72 \mathrm{~h}$, in anaerobic atmosphere (Oxoid Jar with Anaerogen $2.5 \mathrm{~L}$ ). In the first $24 \mathrm{~h}$, a slight turbidity was observed in the culture tube. In the following hours, the lactic acid bacteria culture involved a concentrate turbidity, with a rich deposits, without surface formations.

The morphological characteristics were examined, following ahead the Gram strain protocol according to Bergey's Manual (1984). MRS agar plates display white and creamy colonies (presumptive for LAB). Carefully, the colonies were chosen, separated and purified through consecutive transfers on MRS agar until was obtained a pure culture. The strains were stored at $4^{\circ} \mathrm{C}$ as a relevant technical character, until utilisation (no more two week, Sorescu et al., 2019). For the strains already known (L. paracasei CCM 1837 and $L$. plantarum ATCC 8014) was followed the same protocol.

\section{LAB Phenotypical Identification}

The Catalase Assay

The presence of catalase from a bacterial isolate is obvious when a small amount of bacterial culture from their agar selective medium developed bubbles (effervescence) at addition of $3 \%$ hydrogen peroxide $(3 \%, \mathrm{v} / \mathrm{v})$ (MacFaddin, 2000).

\section{The API 50 CHL}

All strains were identified (genus and species) and characterized based on biochemical evaluation tests using a bioMerieux API 50 CHL test kit according to the manufacturer's instructions (BioMerieux, Marcy l'Etoile, France). The test API 50 CHL put in evidence the enzymatic equipment bacteria, which differs from one species to another. The API $50 \mathrm{CHL}$ consists of 50 microtubes used to study carbohydrates fermentation. The fermentation tests are inoculated with bacterial strain suspension in API 50 CHL medium which rehydrates the substrates. During incubation, the ability of isolate to ferment carbohydrates is indicated by the colour change of the basal medium used, caused by the anaerobic production of acid and detected by the $\mathrm{pH}$ indicator present in the selective medium. The strips are visually examined after 24-72 h. A positive or negative result was determined from the colour change from purple to yellow. The results were then introduced to the API databases using APIwebTM 50 CHL V5.1 and ABIS online software (Stoica and Sorescu, 2017). 


\section{Preservation of Stock Culture}

The LABs were conserved in MRS broth medium containing 20\% (v/v) glycerol as frozen cryoprotectant at $-80^{\circ} \mathrm{C}$. The glycerol were done by homogenized $10 \mathrm{~mL}$ overnight culture (1:10) including $2 \mathrm{~mL}$ sterile glycerol.

\section{LAB Haemolytic Activity}

The overnight pure cultures of LAB isolate, respectively L. paracasei CCM 1837 and L. plantarum ATCC 8014, were streaked onto TSA agar plates (Oxoid, P00163) with 5\% of sheep blood (commercial) followed by incubation at $37^{\circ} \mathrm{C}$, for $24 \mathrm{~h}$. Haemolytic activity was verified based on the ability of strains to lyse blood cells from culture medium. The interpretation was done according to Reuben et al. (2019). Furthermore, Dumitru et al. (2020) present that a clear zone around colonies on TSA medium indicates complete beta hydrolysis ( $\beta$-haemolysis) and the strain must be eliminated for utilization as a probiotic in animal nutrition. According to Prieto et al. (2012) and Seker (2010), non-haemolysis ( $\gamma$-haemolysis with non-change registered in the media) and $\alpha$-haemolysis (a small green zone discoloration around colonies) are considered to be safe.

\section{Crude Enzymes Preparation}

The crude enzyme secreted by LABs (LAB isolate, L. paracasei CCM 1837 and L. plantarum ATCC 8014) was prepared freshly until use. In relation to $1: 10(\mathrm{v} / \mathrm{v})$ of 24 -h-old culture, LAB was inoculated in MRS broth medium and incubated at $37^{\circ} \mathrm{C}$, for $24 \mathrm{~h}$ in aerobic conditions. LABs cell-free supernatant containing crude enzymes was collected by centrifugation at $5000 \mathrm{rpm}, 20$ $\min$ at $4^{\circ} \mathrm{C}$. Until use, the supernatant was kept at $4^{\circ} \mathrm{C}$ (no more than one week, Ho and Sze, 2018).

\section{Evaluating the Enzymatic Activity}

All Lactobacillus spp. were grown in MRS selective medium according to Bergey's Manual (1984). The enzymatic activity was evaluated at 24, 48 and $72 \mathrm{~h}$, at $37^{\circ} \mathrm{C}$ in aerobic conditions, by next methods:

1. Hostettler's method for amylase activity. It is based on the action of $\alpha$ amylase on starch and production of maltose after the hydrolysis process, with 3,5 - dinitrosalicylic acid (DNS), at $\mathrm{pH} 6.9,30^{\circ} \mathrm{C}$, as a colorimetric method. An amylase unit activity (U) corresponds to a quantity of maltose $(\mu \mathrm{mol})$ released under the action of $1 \mathrm{~mL}$ of enzyme preparation in one minute, at $30^{\circ} \mathrm{C}$.

2. Petterson's and Porath's method for cellulase activity. It is based on the enzymatic hydrolysis of carboxymethylcellulose (CMC, Roth) and the dosing of reducing sugars released with 3,5-dinitrosalicylic acid (DNS) colorimetric method. A cellulolytic unit activity (U) represents the amount of enzyme able 
to release from a CMC solution, an amount of reducing sugars, which form with the DNS reagent, the same optical density, equivalent to a milligram of glucose (Jurcoane et al., 2006).

\section{Statistical Analysis}

The graphics for the present study were generated using SigmaPlot V.14.5 software (San Jose, CA, USA). and some of the parameters were determined using MS Excel 19.

\section{RESULTS AND DISCUSSION}

Characterization and isolation of lactic acid bacteria

Species of LAB are probiotics sources in animal feed due to their properties to enhance the GIT health and performance. Furthermore, LAB are known as producer of lactic acid from carbohydrate fermentation, and the extracellular metabolites have been demonstrated to be a potential substitute for antibiotics to improve meat quality and broiler chicken, laying hens, and piglets performance (Lim et al., 2019; Kareem et al., 2016; Loh et al., 2013). The strain isolated from ileum content of turkey appears as punctiform colonies at $24 \mathrm{~h}$ with a Gram-positive staining. In MRS broth, after $24-48 \mathrm{~h}$ in aerobiosis, intense turbidity was noticed, with abundant deposits without surface formations, which phenotypically correspond to the genus Lactobacillus. A summary of morphology characteristics of our isolate identified as L. acidophillus IBNA 09 (LA), comparatively with LC and LP strains can be observed in Table 1.

Table 1. Colonies and cell morphology of Lactobacillus strains

\begin{tabular}{|c|c|c|c|}
\hline LAB & Colony morphology & $\begin{array}{l}\text { Gram } \\
\text { stain }\end{array}$ & Shape \\
\hline LA & $\begin{array}{l}\text { round, opaque, whitish, with } \\
\text { irregular margins, } 1.0 \mathrm{~mm} \text { up to } 1.5 \\
\text { mm } \emptyset \text { after } 48 \mathrm{~h} \text {, in anaerobiosis }\end{array}$ & + & $\begin{array}{l}\text { Bacilli, thin, rods, isolated, } \\
\text { short chains or in small } \\
\text { irregular piles, immobile, } \\
\text { non-spore forming }\end{array}$ \\
\hline LC & $\begin{array}{l}\text { small colonies, } 0.2-0.5 \mathrm{~mm} \varnothing \text { after } \\
48 \mathrm{~h} \text {, anaerobiosis/microaerophile, } \\
\text { regular margins, with white-beige } \\
\text { pigment, sediment formation }\end{array}$ & + & $\begin{array}{l}\text { Isolated, arranged in short } \\
\text { chains, non-spore forming }\end{array}$ \\
\hline LP & $\begin{array}{l}\text { Small colonies with smooth aspect } \\
\text { (round, regular margins), } 0.5-2.0 \\
\text { mm } \emptyset \text {, microaerophile, white-beige } \\
\text { pigment, sediment formation }\end{array}$ & + & $\begin{array}{l}\text { rods, isolated, short chains } \\
\text { or in small irregular piles, } \\
\text { immobile, non-spore } \\
\text { forming }\end{array}$ \\
\hline
\end{tabular}

+: positive; LA- L. acidophillus IBNA 09; LC- L. paracasei CCM 1837 (IBNA 04); LP- L. plantarum ATCC 8014 (IBNA 03).

Aerobiosis was done in 0xoid Jar with Anaerogen $2.5 \mathrm{~L}$; colonies size were measured with a ruler as millimeter $(\mathrm{mm})$. 
Our results based on morphological data and presented in Table 1 are simillar with Hoque et al. (2010) report which affirmed that Lactobacillus genus is genetically and physiologically a diverse group of rod-shaped, Grampositive, with catalase-negative and non-spore-forming bacteria.

The colonies characteristics found after Gram staining technique included our isolate as a strain from Lactobacillus group. The isolate presented similar traits to the finding of Kabir et al. (2016), morphological traits which are supported by another researcher (Dumitru et al., 2020; Sorescu et al., 2021; Mannan et al., 2017).

\section{LAB Phenotypical Identification}

All strains were catalase-negative. The identity of the new strain was confirmed by sugars fermentation and biochemical test API 50 CHL V5.1 („excellent identification”, L. acidophilus 2, 99.9\% ID) and ABIS online ( $L$. acidophilus 88\%) following the manufacturer instructions and used in several reports (Dumitru et al., 2021; Sorescu et al., 2019). Furthermore, the phenotypical profile of L. paracasei CCM 1837 (LC) and L. plantarum ATCC 8014 (LP), strains that were purchased in the form of freeze-dried, were used as reference strains. In addition, after revitalized in MRS broth medium and identified by API 50CHL Biomerieux, all three strains of Lactobacillus involve different fermentation of monosaccharide and disaccharide. The strains capability in fermenting carbohydrates was observed by the discoloration of the basal medium from purple to yellow (Figure 1).
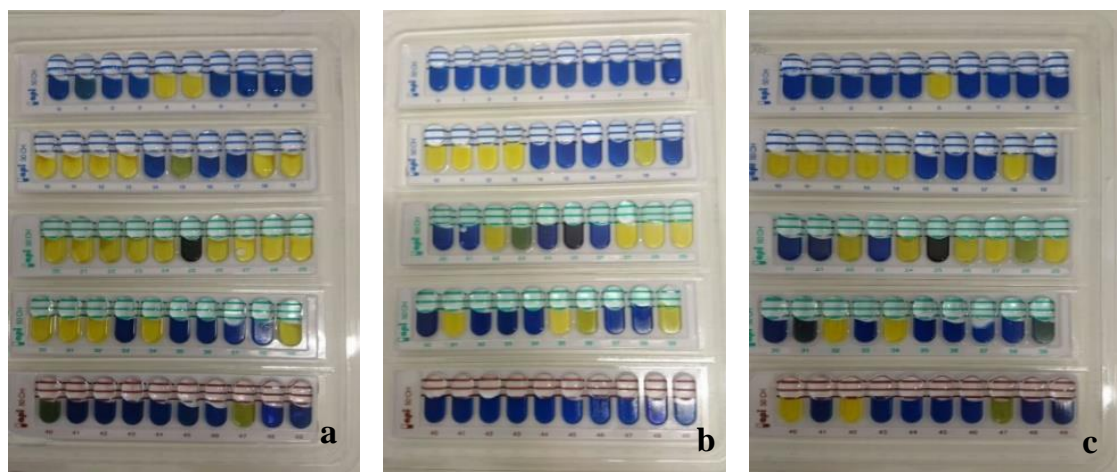

Figure 1. API 50 CHL strips inoculated with Lactobacillus species (a - L. acidophilus IBNA 09; b - L. paracasei CCM 1837; c - L. plantarum ATCC 8014)

In this study, the results of sugar fermentation were presented in Table 2. 
Table 2. The results obtained with API 50 CHL for Lactobacillus strains

\begin{tabular}{|c|c|c|c|}
\hline \multirow[b]{2}{*}{ Biochemical Test } & \multicolumn{3}{|c|}{ Strains } \\
\hline & $\begin{array}{l}\text { L. acidophilus } \\
\text { IBNA } 09\end{array}$ & $\begin{array}{c}\text { L. paracasei } \\
\text { CCM } 1837\end{array}$ & $\begin{array}{c}\text { L. plantarum ATCC } \\
8014\end{array}$ \\
\hline Glycerol & - & - & - \\
\hline Erythritol & - & - & - \\
\hline D-arabinose & - & - & - \\
\hline L-arabinose & - & - & + \\
\hline D-ribose & - & + & + \\
\hline D-xylose & - & - & - \\
\hline L-xylose & - & - & - \\
\hline D-adonitol & _- & - & _- \\
\hline Methyl- $\beta D$-xylopyranoside & - & - & - \\
\hline D-galactose & + & + & + \\
\hline D-glucose & + & + & + \\
\hline D-fructose & + & + & + \\
\hline D-mannose & + & + & + \\
\hline L-sorbose & - & + & - \\
\hline L-rhamnose & - & - & $?$ \\
\hline Dulcitol & - & - & - \\
\hline Inositol & - & - & - \\
\hline D-mannitol & + & $+3 / 6$ days & + \\
\hline D-sorbitol & - & - & + \\
\hline Methyl- $\alpha$ D-mannopyranoside & - & _- & + \\
\hline Methyl- $\alpha$ D-glucopyranoside & - & + & + \\
\hline $\mathrm{N}$-acetylglucosamine & + & - & + \\
\hline Amygdalin & - & + & + \\
\hline Arbutin & - & + & + \\
\hline Esculin & + & + & + \\
\hline Salicin & - & + & + \\
\hline D-cellobiose & + & + & + \\
\hline D-maltose & + & $?$ & + \\
\hline D-lactose & + & + & + \\
\hline D-melibiose & - & - & + \\
\hline D-saccharose (sucrose) & + & - & + \\
\hline D-trehalose & - & + & + \\
\hline Inulin & _- & _- & _- \\
\hline D-melezitose & - & + & + \\
\hline D-raffinose & + & - & - \\
\hline Starch & + & + & - \\
\hline Glycogen & - & - & - \\
\hline Xylitol & - & - & - \\
\hline Gentibiose & $?$ & $?$ & + \\
\hline D-turanose / $72 \mathrm{~h}$ & + & + & $+3-6$ days \\
\hline D-lyxose & - & -;? 3-6 days & - \\
\hline D-tagatose & - & + & - \\
\hline D-fucose & - & - & - \\
\hline L-fucose & - & - & - \\
\hline D-arabitol & - & - & - \\
\hline L-arabitol & - & - & _- \\
\hline Potassium gluconate & ? & $?$ & ? \\
\hline Potassium 2-ketogluconate & - & - & - \\
\hline Potassium 5-ketogluconate & - & - & - \\
\hline
\end{tabular}

+: positive test; -: negative test; ?: dubious, weekly 
It was obtained a good percentage of identification for $L$. paracasei CCM 1837 and L. plantarum ATCC 8014 by API 50 CHL (L. paracasei spp. paracasei 1 , good identification to the genus $48-51 \%$ ID; L. plantarum 1, very good identification, ID 99.9\%) and ABIS online (L. paracasei spp. paracasei, 90\%; L. plantarum, 91\%). Mannan et al. (2017) and Na-Kyoung et al. (2008) present similar results of Lactobacillus bacteria fermentation. All the isolates fermented galactose, glucose, fructose, mannose, esculin, cellobiose, lactose, and turanose. The difference of our isolate compared with LC and LP consist in their capacity to ferment D-raffinose substrate (positive).

\section{Preservation of Stock Culture}

Regarding the storage conditions, all strains were conserved at $-80^{\circ} \mathrm{C}$, with the addition of $20 \%$ glycerol as cryoprotectant agent and can be found in the intern Bacterial Collection of IBNA Balotesti, Department of Animal Nutrition and Biotechnology as L. acidophilus IBNA 09, L. paracasei CCM 1837 (IBNA 04), and L. plantarum ATCC 8014 (IBNA 03).

\section{LAB Haemolytic Activity}

The present Lactobacillus strain identified as L. acidophilus was found nonhemolytic on a TSA agar after $24 \mathrm{~h}$, at $37^{\circ} \mathrm{C}$. In addition, LC and LP reference strains, involved similar results as alpha haemolytic activity. All strains are considered a safe prerequisite for application as a probiotics source in poultry. Previously report (Olufemi et al., 2018), affirmed that popular of LAB strains are non-haemolytic. Therefore, apart from other advantageous properties, sourcing of probiotic strains isolated from their natural niche, is most ideal, as such bacterial strains are familiar with the gastrointestinal tract of the host, and can naturally multiply and express the desired beneficial effects better than strains isolated from other sources (Reuben et al., 2019). The results from our research correspond with FAO (Food and Agriculture Organization of the United Nations) guidelines which affirmed that until to use a bacterial strain as probiotic supplementation is recommended to be safe without any negative effect in the host.

\section{Evaluating the Amylase Activity}

Extracellular amylase of LA, LC, and LP that grown in selective medium was subsequently determined in this study. The calibration maltose curve was used to estimate the amylase activity values (Figure 1) and the optical density (OD) at $546 \mathrm{~nm}$ was measured. 


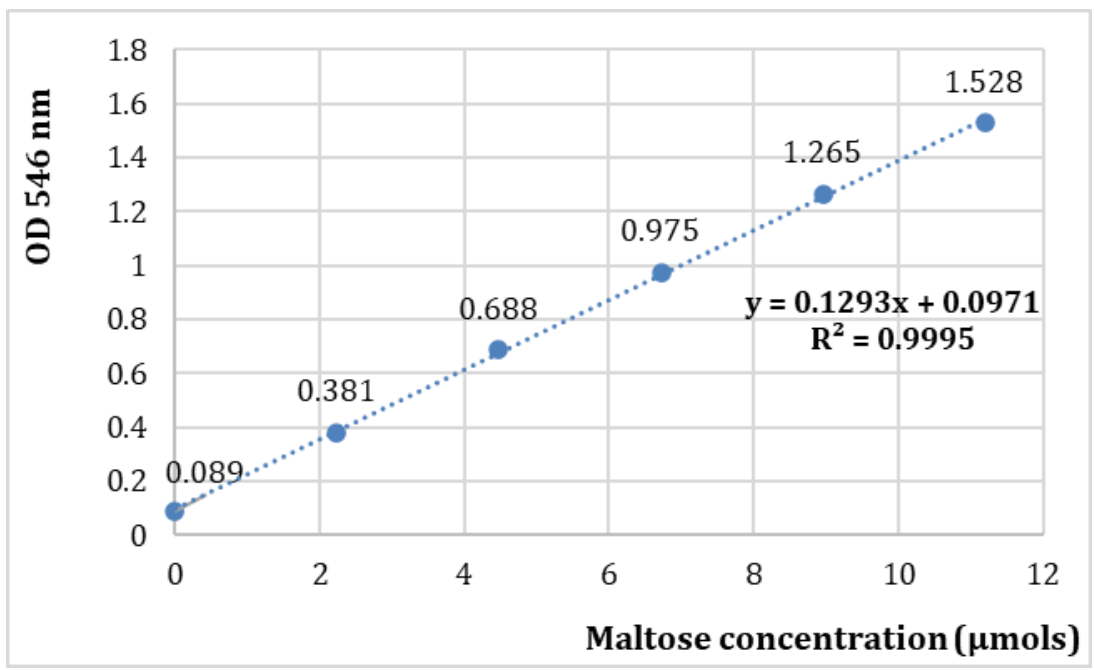

Figure 1. Standard curve of maltose

The results obtained demonstrated that the specific extracellular enzymatic activity was varied considerably. In the first $24 \mathrm{~h}$ of incubation, from all Lactobacillus strains, only LA ranked highest amylase activity $(5.10 \pm$ $0.179 \mathrm{U} / \mathrm{mL})$, followed by LC $(0.12 \pm 0.002 \mathrm{U} / \mathrm{mL})$. This finding was very interesting because, at $48 \mathrm{~h}$, our isolate involved a slow decrease of amylase level activity (4.99 $\pm 0.409 \mathrm{U} / \mathrm{mL}$ ), while LC registered a slight increase of amylase production $(0.15 \pm 0.001 \mathrm{U} / \mathrm{mL})$. Based on a standard curve of maltose, LP strain during $72 \mathrm{~h}$ did not show any amylase activity (Figure 2).

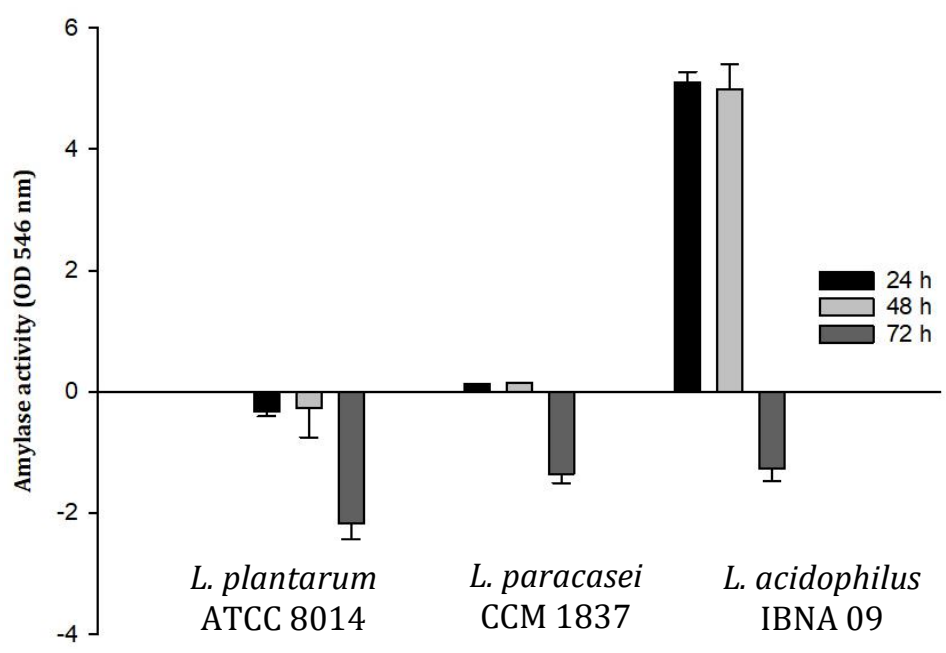

Figure. 2. The amylase activity of Lactobacillus strains by Hostettler's method Data are represented as means \pm standard error of means (SEM) $(n=3)$ 
Rapid hydrolysis of starch is an important aspect in fermentation processes (Oguntoyinbo and Narbad, 2015). During exponential stage of growth, a good producer of amylase was seen in the first $24 \mathrm{~h}$ for LA followed by LC. The secretion of amylase by LA continued to be visible at $48 \mathrm{~h}$ under the assay conditions, confirming thus the statement of Fossi and Tavea (2013) who specified a solid relationships between cell growth and amylase production. No amylase activity was detected for LP. Lactobacillus spp. involve different extracellular amylase production during fermentation process. Similar data were presented in Lee et al. (2019) report where seven $L$. plantarum strains were compared based on enzymatic activity in MRS medium. Additionally, the amylase production of LP is in accordance with $L$. plantarum strain of Dumitru et al. (2018) study, where the amylase activity registered was total absent in MRS broth medium. In addition, the fermentation capacity of amylase can be observed in API 50 CHL test, where from all LAB, LA and LC have the ability to hydrolyze starch substrate. This result suggests that LA is efficient to degrading starch and with a minimum activity for LC.

Amylolytic LAB uses starch biomass and converts into lactic acid in a single stage of fermentation which represents the primary step of process with a rapidly action of sugars degradation in substances as acids and alchols (Fossi and Tavea, 2013). The decline of strains growth and amylase secretion was observed at LP and LC and could be attributed as reported Singh et al. (2006) to the rise of lactic acid concentration as the end product of lactic acid bacteria capable of fermenting different sugars (Klaenhammer and De Vos, 2011).

\section{Evaluating the Cellulase Activity}

Extracellular cellulase by DNS method of Lactobacillus strains in MRS broth medium was measured during $24-72 \mathrm{~h}$. For evaluation of cellulase activity, the absorbance was measured at $640 \mathrm{~nm}$. The cellulase activity of LC at $24 \mathrm{~h}$ was ranked highest $(0.63 \pm 0.181 \mathrm{U} / \mathrm{mL})$, followed by LA $(0.59 \pm 0.021$ $\mathrm{U} / \mathrm{mL}$ ). Regarding the LP strain, the production of cellulase could not be determined in first $48 \mathrm{~h}$. However, certain bacterial species present different responses to diverse environmental conditions, $\mathrm{pH}$ values, and their fermentation capacity can improve the fermentation efficiency, quality, aerobic stability, and antimicrobial capacity by mixing them as a probiotic source in animal feed (Sun et al., 2012; Zhao et al., 2021). Based on their metabolism, LAB can metabolise several monosaccharides (e.g. fructose, glucose, galactose, and xylose) which are lignocellulosic components from diverse raw materials (Tarran and Mazzoli, 2018). 


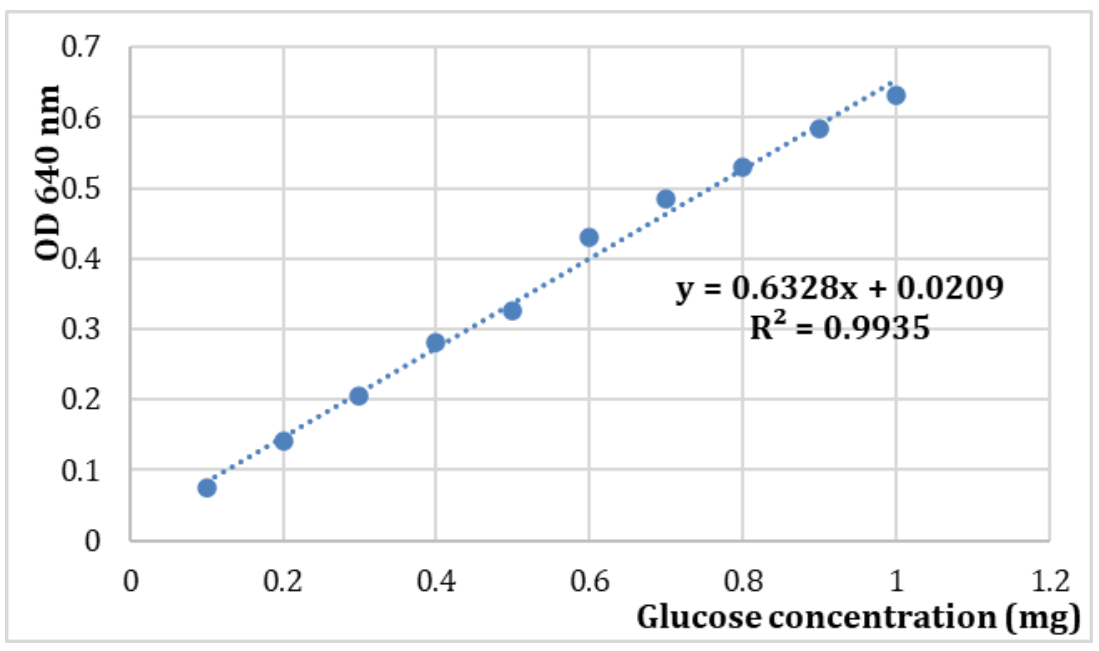

Figure 3. Standard curve of glucose

The addition of LAB cultures with cellulase capacity of production in feedstuffs can degrade cellulose to monosaccharides or oligosaccharides, thus improving LAB proliferation to obtain higher fermentation quality. Experimentally, lactic acid bacteria culture based on cellulase activity was performed to determine their ability to consume cellulose by using optical density as a growth parameter.

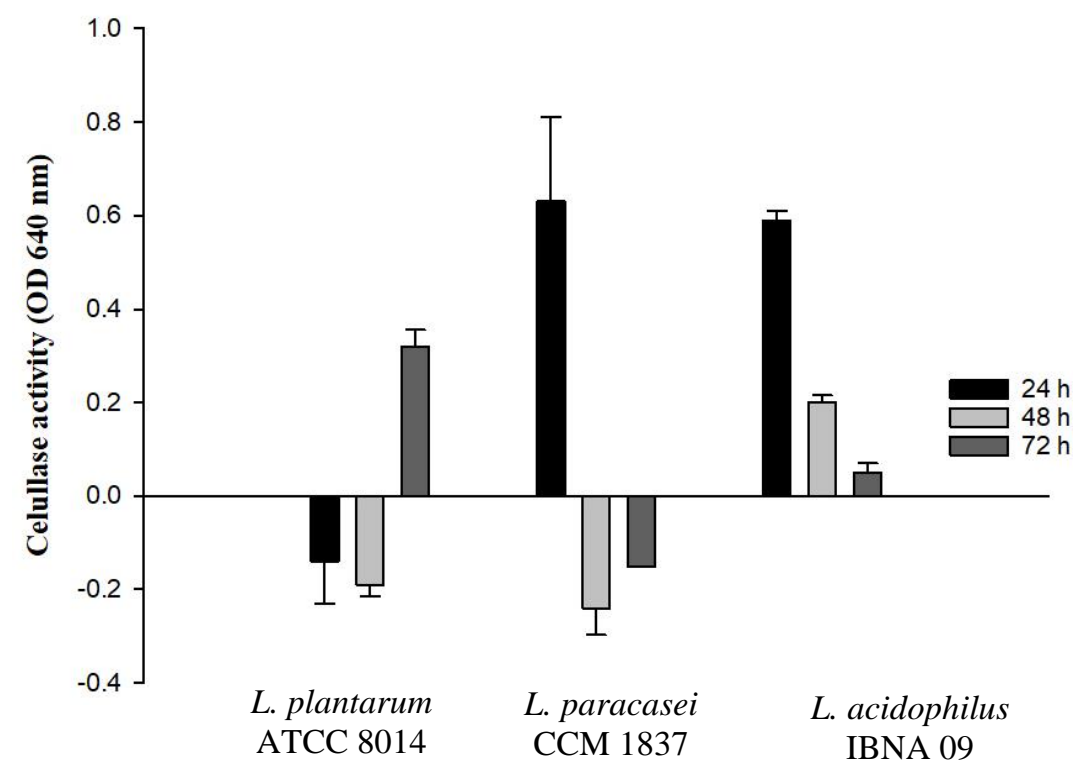

Figure 4. The cellulase activity of Lactobacillus strains by DNS method Data are represented as means \pm standard error of means (SEM) $(n=3)$ 
In Figure 4 can be observed that, at $48 \mathrm{~h}$, the cellulase LA secretion decrease slowly $(0.2 \pm 0.016 \mathrm{U} / \mathrm{mL}) v s$. LP and LC strain where the enzyme production was totally absent. Therefore, at $72 \mathrm{~h}$, the enzymatic capacity of LP strain was activated, followed by a cellulase secretion $(0.32 \pm 0.036 \mathrm{U} / \mathrm{mL})$. For bacteria to hydrolyze and degrade insoluble cellulose from agriculture lignocellulosic biomass, the production of extracellular cellulase is essential (Deutscher, 2008). The secretion of enzymes can be affected by several factors as temperature, $\mathrm{pH}$, and other extreme conditions found by bacteria cells in animal body.

\section{CONCLUSION}

In conclusion, from all LAB, L. acidophilus IBNA 09 exhibited notably extracellular enzymatic activity. Amylase production was registered at 24-48 h, comparatively with cellulase where the activity was observed during the entire period. These results suggest that L. acidophilus IBNA 09 isolated for turkey ileum content have potential probiotic traits as a suitable candidate for amylase and cellulase production, and can be used to improve raw materials fermentation and process of digestion in animal nutrition.

\section{ACKNOWLEDGEMENTS}

This study was sponsored by the Ministry of Agriculture and Rural Development through the project ADER 9.1.4 and by the Romanian Ministry of Research, Innovation and Digitization (Project No. PN19-09.01.04).

\section{REFERENCES}

Anee, I.J., Alam, S., Begum, A., Shahjahan, R.M., Khandaker, A.M., 2021. The role of probiotics on animal health and nutrition. JoBAZ, 82(52), 1-16.

Bakari, D., Tatsadjieu, N.L., Mbawala, A., Mbofung, C.M., 2011. Assessment of physiological properties of some lactic acid bacteria isolated from the intestine of chickens use as probiotics and antimicrobial agents against enteropathogenic bacteria. Innov Rom Food Biotechnol. 8, 33-40.

Bedford, M.R., Partridge, G.G., 2001. Enzymes in farm animal nutrition. $2^{\text {nd }}$ edition. Library of Congress Cataloging-in-Publication Data, UK.

Ciurescu, G., Dumitru, M., Gheorghe, A., Untea, A., Drăghici, R., 2020. Effect of Bacillus subtilis on growth performance, bone mineralization, and bacterial population of broilers fed with different protein sources. Poult Sci. 99, 5960-5971.

Deutscher, J., 2008. The mechanisms of carbon catabolite repression in bacteria. Curr Opin Microbiol. 11, 87-93. 
Dumitru, M. Vodnar D.C., Elemer, S., Ciurescu, G., Habeanu, M., Sorescu, I., Georgescu, S.E., Dudu, A., 2021a. Evaluation of non-encapsulated and microencapsulated lactic acid bacteria. Appl Sci. 11, 1-15.

Dumitru, M., Ciurescu, G., Sorescu, I., 2020. In vitro evaluation of some probiotic properties of Lactobacillus strains isolated from chickens' gut. Scientific Papers: Animal Science and Biotechnologies, 53(1), 4451.

Dumitru, M., Habeanu, M., Sorescu, I., Tabuc, C., 2021b. Bacillus spp. as a supplemental probiotic in diets for weaned piglets. S Afr J Anim Sci. 51(5), 578-586.

Dumitru, M., Sorescu, I., Ciurescu, G., Habeanu M., 2021. Isolation, identification, preservation and determinations of lactic acid bacteria from chicken's gut content at 26 days old. Rom Biotech. Lett. 26(4), 2765-2772.

Dumitru, M., Sorescu, I., Jurcoane, Ș., Cîmpeanu, G., Tabuc, C., Hăbeanu, M., 2017. Assesing of morpfological, cultural, biochimical profile and enzymatic activity of a Lactobacillus paracasei CCM 1837 strain. Academy of Romanian Scientists, Ann Biol Sci. 6(2), 22-31.

Dumitru, M., Tabuc, C., Jurcoane, Ș., 2016. Evaluarea activității enzimatice a unor specii bacteriene utilizate în biopreparate enzimatice pentru hrana animalelor. Analele IBNA, 31, 93-101, Balotești.

Dumitru, M., Tabuc, C., Jurcoane, S., 2018. Obtaining a feed additive based of Lactobacillus plantarum strain. Scientific Papers. Series A. Agronomy, LXI(2), 115-122. ISSN 2285-5785.

Food and Agriculture Organization of the United Nations (FAO, 2006). Probiotics in food. Health and nutritional properties and guidelines for evaluation. Paper 85. Chapter „Guidelines for the assessment of probiotic microorganisms", 4. www.fao.org/3/a0512e/a0512e.pdf.

Fossi, B.T., Tavea, F., 2013. Application of amylolytic Lactobacillus fermentum 04BBA19 in fermentation for simultaneous production of thermostable $\alpha$-amylase and lactic acid. Chapter 27.

Ho, J.C.K., Yin Sze, L., 2018. Isolation, identification and characterization of enzyme-producing lactic acid bacteria from traditional fermented foods. Bioscience Horizons: Int J Stud Res. 11, 1-11.

Holt, J.G., 1984. Bergey's manual of systematic bacteriology. Baltimore: Williams and Wilkins.

Hoque, M.Z., Akter, F., Hossain, K.M., Rahman, M.S.M., Billah, M.M., Islam K.M.D., 2010. Isolation, identification and analysis of probiotic properties of Lactobacillus spp. from selective regional yoghurts. WJDFS 5(1), 39-46.

Jurcoane, S.., Diguță F.C., Groposila, C.D.G., 2006. General Biotechnology. Practical Applied, Bucharest.

Kabir, S.M., Mushfiqur Rahman, S.M., Neogi, S.B., Rahman, M., Khan, M.S.R., 2016. Isolation, identification, molecular characterization and 
screening of probiotic activities of Lactobacillus species from poultry sources at live bird markets in Mymensingh, Bangladesh. Asian Australas J Biosci Biotechnol. 1(1), 54-65.

Kareem, K.Y., Loh, T.C., Foo, H.L., Akit, H., Samsudin, A.A., 2016. Effects of dietary postbiotic and inulin on growth performance, IGF1 and GHR mRNA expression, faecal microbiota and volatile fatty acids in broilers. BMC Veter Res. 12(163), 1-10.

Kizerwetter-Swida, M., Bineak, M., 2016. Assessment of potentially probiotic properties of Lactobacillus strains isolated from chickens. Pol J Vet Sci. 19(1), 15-20.

Klaenhammer, T.R. De Vos, W.M., 2011. An incredible scientific journey. The evolutionary tale of the lactic acid bacteria. In: Ledeboer A, Hugenholtz J, Kok J, Konings W, Wouters J (ed.) The $10^{\text {th }}$ LAB symposium. Thirty years of research on lactic acid bacteria. 24 Media Labs, 1-11.

Latorre, J.D., Velasco, X.H., Wolfenden, R.E., Vicente, J.L., Wolfenden, A.D., Menconi, A., Bielke, L.R., Hargis, B.M., Tellez, G., 2016. Evaluation and selection of Bacillus species based on Enzyme Production, antimicrobial activity, and biofilm synthesis as direct-fed microbial candidates for poultry. Front Vet Sci. 3(95), 1-9, USA.

Lee, F.H., Wan, S. Y., Foo, H. L., Loh, T. C., Mohamad, R., Abdul Rahim, R., \& Idrus, Z., 2019. Comparative study of extracellular proteolytic, cellulolytic, and hemicellulolytic enzyme activities and biotransformation of palm kernel cake biomass by lactic acid bacteria isolated from Malaysian foods. IJMS, 20(20), 4979. doi:10.3390/ijms20204979

Lim, Y.H., Foo, H.L., Loh, T.C., Mohamad, R., Abdullah, N., 2019. Comparative studies of versatile extracellular proteolytic activities of lactic acid bacteria and their potential for extracellular amino acid productions as feed supplements. J Anim Sci.Biotechnol. 10(15), 1-13.

Loh, T.C., Thanh, N., Foo, H.L., Hair-Bejo, M., 2013. Effects of feeding metabolite combinations from Lactobacillus plantarum on plasma and breast meat lipids in Broiler Chickens. Braz J Poult Sci. 15, 307-316.

MacFaddin, J.F., 2000. Biochemical tests for identification of medical bacteria. 3rd ed. Lippincott Williams \& Wilkins, Philadelphia, PA.

Mannam, S.J., Rezwan, R., Rahman, M., Begum, K., 2017. Isolation and biochemical characterization of Lactobacillus species from yogurt and cheese samples in dhaka metropolitan area. Bangladesh J Pharmacol. 20(1), 27-33.

Menconi, A., Morgan, M. J., Pumford, N.R., Hargis, B.M., Tellez, G., 2013 a. Physiological properties and Salmonella growth inhibition of probiotic Bacillus strains isolated from environmental and poultry sources. Int J Bacteriol. 1-8. 
Na-Kyoung, L., Yun, C.W., Kim, S.W., Chang, H.I., Kang,, C.W., Paik H.D., 2008. Screening of lactobacilli derived from chicken feces and partial characterization of Lactobacillus acidophilus A12 as animal probiotics. J Microbiol Biotechnol. 18(2), 338-342.

Oguntoyinbo, F.A., Narbad, A., 2015. Multifuctional properties of Lactobacillus plantarum strains isolated from fermented cereal foods. J. Funct. Foods, 17, 621-631.

Olufemi, F.O., Chijioke, O.M., Popoola, S.T., Oluwafemi, O.F., 2018. In vitro study of potential probiotic lactic acid Bacteria isolated from the gut of chickens in Abeokuta, Nigeria. Alexandria J Vet Sci. 58(1), 73-84.

Padmavathi, T., Bhargavi, R., Priyanka, P.R., Niranjan, N.R., Pavitra, P.V., 2018. Screening of potential probiotic lactic acid bacteria and production of amylase and its partial purification. J Genet Eng and Biotechnol. 16(2), 357-362.

Pieper, R., Janczyk, P., Schumann, R., Souffrant, W.B., 2006. The intestinal microflora of piglets around weaning - with emphasis on lactobacilli. Archiva Zootechnica, 9, 28-40.

Prieto, M.L., O’Sullivan, L., Tan, S.P., McLoughlin, P., Hughes, H., Gutierrez, M., Jonathan, A., Lane, J., Hickey, R.M.G., Lawlor, P.G., Gardiner, G.E., 2014. In vitro assessment of marine Bacillus for use as livestock probiotics. Mar Drugs 12, 2422-2445.

Reuben, R.C., Roy, P.C., Sarkar, S.L., Alam, R.-U., Jahid, I.K., 2019. Isolation, characterization, and assessment of lactic acid bacteria toward their selection as poultry probiotics. BMC Microbiology, 19(1), 1-20.

Richards, J.D., Gong, J., C.F.M. de Lange, 2005. The gastrointestinal microbiota and its role in monogastric nutrition and health with an emphasis on pigs: current undestanding, possible modulations, and new techologies for ecological studies. Novus International. Can J Anim Sci. 85(4), 421435.

Seker, E., 2010. Identification of Candida species isolated from bovine mastitis milk and their in vitro hemolytic activity in Western Turkey. Mycopathologia, 169, 303-308.

Singh, S.K., Ahmed, S.U., Pandey, A., 2006. Metabolic engineering approaches for lactic acid production. Process Biochem. 41(5), 991-1000.

Sorescu, I., Dumitru, M., Ciurescu, G., 2019. Lactobacillus spp. and Enterococcus faecium strains isolation, identification, preservation and quantitative determinations from turkey gut content. Rom. Biotechnol. Lett. 24, 41-49.

Sorescu, I., Dumitru, M., Ciurescu, G., 2021. Lactobacillus spp. strains isolation, identification, preservation and quantitative determinations from gut content of 45 days old chickens. Rev Bras Cienc Avic. 23(1), 1-7. 
Stoica, C., Sorescu, I., 2017. ABIS online - Advanced Bacterial Identification Software, an original tool for phenotypic bacterial identification. Regnum Prokaryotae - www.tgw1916.net.

Sun, Q., Gao, F., Zhu, Y.U., Tao, Y., Zhao, S., Cai, Y., 2012. Fermentation quality and chemical composition of shrub silage treated with lactic acid bacteria inoculants and cellulase additives. Anim. Sci. J., 83, 305-309.

Tarraran, L., Mazzoli, R., 2018. Alternative strategies for lignocellulose fermentation through lactic acid bacteria: the state of the art and perspectives. FEMS Microbiology Letters, 365(15), 1-14.

Vamanu, A., Popa, O., Câmpeanu, Gh., Dumitru, I.F., 2015. Biological, biotechnological and pharmacological studies on the use of probiotic products.

Walter, J., 2008. Ecological role of Lactobacilli in the gastrointestinal tract: implication for fundametal and biomedical research. Minireviews. Appl Environ Microbiol. 74(16), 4985-4996, Nebraska.

Yelnetty, A., Purnomo. H., Mirah, P.A., 2014. Biochemical characteristics of lactic acid bacteria with proteolytic activity and capability as starter culture isolated from spontaneous fermented local goat milk. J Nat Sci Res. 4(10),137-147.

Zhao, C., Wang, L., Ma, G., Jiang, X., Yang, J., Lv, J., Zhang, Y., 2021. Cellulase interacts with lactic acid bacteria to affect fermentation quality, microbial community, and ruminal degradability in mixed silage of soybean residue and corn stover. Animals, 11(2), 334. 